\title{
ON THE CONTRIBUTION OF HISTORIAN S.V. KARASEV TO THE STUDY OF THE TOPIC «JAPANESE PRISONERS OF WAR IN THE SOVIET UNION (1945-1956)» IN RUSSIAN HISTORIOGRAPHY
}

\author{
Sergey Serebrennikov ${ }^{1}$
}

\begin{abstract}
The article considers for the first time the contribution of the Russian historian S. V. Karasev to the study of the topic "Japanese prisoners of war in the territory of the Soviet Union (1945-1956)". This topic is relatively new in Russian historiography; until 1990, it was among the "closed", historians did not have access to archival documents. Sergey Vladimirovich Karasev, Professor of Irkutsk state technical University belongs to a narrow number of candidates and doctors of Sciences, who made a significant contribution to the study of the topic "Japanese prisoners of war in the Soviet Union (1945-1956)" in Russian historiography.
\end{abstract}

Key words: Japanese prisoners of war; Russian historiography; archives, publications; dissertations; conferences; monographs.

doi: http://doi.org/10.15350/F_6/14

Доктор исторических наук, профессор Иркутского государственного технического университета Сергей Владимирович Карасев принадлежит к числу маститых отечественных исследователей темы «Японские военнопленные на территории Советского Союза (1945-1956 гг.)».

С.В. Карасев родился 25 января 1959 г. в городе Львове Украинской ССР. После окончания в 1981 году механико-машиностроительного факультета Львовского политехнического института он два года работал инженером-конструктором научно-исследовательского радиотехнического института. В 1983 г. был призван в ряды Вооруженных Сил СССР, где прослужил до 2007 г. Подполковник запаса.

Первые публикации С.В. Карасева о японских военнопленных на территории Читинской области после второй мировой войны увидели свет в конце 1990-х - начале 2000-х гг. в период подготовки им кандидатской диссертации.

К этому времени российская историческая наука проделала небольшой длиною в десять лет - путь. До конца 1980-х годов тема «Японские военнопленные на территории Советского Союза (1945-1956 гг.)» относилась в СССР к «закрытым», так как не укладывалась в русло идеологических установок ЦК КПСС, а историки не имели доступа к архивным материалам. В 1990-е годы серьезный прорыв в исследовании темы сделали сибирские историки С.И. Кузнецов и О.Д. Базаров, историк из Владивостока Е.Ю. Бондаренко и, отчасти, исследователь из Хабаровска М.А. Кузьмина.

Кандидатская диссертация «Японские военнопленные на территории Читинской области (1945-1949 гг.)» была успешно защищена С.В. Карасевым в 2002 году на заседании диссертационного совета Д.212.074.05 при Иркутском государственном университете [1]. Вскоре С.В. Карасев опубликовал ее в виде монографии [2].

После защиты диссертации историк целеустремленно стал работать по теме докторской диссертации. Напряженный пятилетний период после защиты канди-

\footnotetext{
1Sergey Serebrennikov, candidate of historical sciences, Kemerovo, Russia.
} 
датской диссертации (2003-2007 гг.) вместил в себя публикацию четырехмонографий [3-6] и 13-ти научных статей [7, с. 37-38].

В 2007 г. в Диссертационном совете при Институте монголоведения, буддологии и тибетологии Сибирского Отделения РАН состоялась защита С.В. Карасевым докторской диссертации «История плена: советско-японская война и ее последствия (1945-1956 гг.)» [8]. Научным консультантом диссертанта был С.И. Кузнецов, который ранее был его руководителем по кандидатской диссертации. Тесное научное сотрудничество с флагманом российской историографии 1990-х годов темы «Японские военнопленные на территории Советского Союза (1945-1956 гг.)» С.И. Кузнецовым дало многое для С.В. Карасева.

С.В. Карасев является единственным российским историком, который и в кандидатской диссертации, и в докторской исследовал данную тему [9]. вопросы:

В отличие от многих специалистов, С.В. Карасев более глубоко изучил такие

- установление численности военнослужащих японской национальности, оказавшихся в советском плену после Второй мировой войны, в том числе военнослужащих высшего командного состава и лиц, приравненных к ним по занимаемой должности до пленения;

- обстоятельства пленения и содержания в советском плену императора Маньчжоу-Го Пу И;

- процесс размещения на территории СССР японских военнопленных;

- трудовое использование, медицинское и продовольственное обеспечение японских военнопленных, размещенных в Читинской области;

- политическая работа среди японских военнопленных в Читинской области;

- работа оперативно-чекистских подразделений с японскими военнопленными в советских лагерях.

Научный багаж, как и потенциал С.В. Карасева многогранен. Помимо изучения вопросов, связанных с пребыванием на территории СССР японских военнопленных, он много внимания уделил

- выявлению готовности японских вооруженных сил к ведению боевых действий против Советского Союза;

- рассмотрел состав, структуру, тактические принципы ведения боевых действий японской армии против войск РККА;

- исследовал вопросы идеологической работы с японскими военнослужащими и в предвоенный период, и в ходе Советско-японской войны 1945 г.;

- определил формы и методы советской идеологической работы с местным, в том числе и русским, населением на территориях занятых войсками РККА в ходе Советско-японской войны 1945 г.;

- исследовал процесс пленения японских военнослужащих.

Отметим также, что С.В. Карасев является единственным российским историком, подготовившим (в одиночку!) сборник документов о пребывании японских военнопленных на территории СССР [10]. Данный сборник выдержал два издания и до появления солидного издания «Японские военнопленные в СССР: 1945-1956», подготовленного В.А. Гавриловым и Е.Л. Катасоновой [11] был единственным, посвященным непосредственно пребыванию японских военнопленных в СССР.

Бывший военный, очевидно, глубже, чем многие, понимает некоторые аспекты, характеризующие идеологическую и морально-психологическую подготовку японских военнослужащих в японской армии, политическую работу среди японских военнопленных в лагерях НКВД-МВД СССР. Поэтому его научные работы по этим проблемам вызывают большой интерес. 
Сергею Владимировичу Карасеву всего 60 лет. Можно не сомневаться в том, что значительный потенциал ученого будет воплощен в новые монографии и другие значимые научные публикации и хочется надеяться, что исследование темы «Японские военнопленные в СССР» будет продолжено.

References

[1] Карасев С. В. Японские военнопленные на территории Читинской области, 1945-1949 гг.: диссертация ... кандидата исторических наук: 07.00.02. / С. В. Карасев. - Иркутск, 2002. 225 c.

[2] Карасев С. В. Японские военнопленные на территории Читинской области (1945-1949 гг.) / С. В. Карасев. - Иркутск: Изд-во ИрГТУ, 2003. - 153 с.

[3] Карасев С. В. Японские военнопленные на территории Читинской области (1945-1949 гг.) / С. В. Карасев. - Иркутск: Изд-во ИрГТУ, 2003. - 153 с.

[4] Карасев С. В. Японская армия в советско-японской войне 1945 г. и вопросы плена / С. В. Карасев. - Иркутск: Изд-во ИрГТУ, 2004. - 77 с.

[5] Карасев С. В. Вопросы идеологической работы в ходе советско-японской войны 1945 года / С. В. Карасев. - Иркутск: Изд-во ИрГТУ, 2006. - 96 с.

[6] Карасев С. В. Проблемы плена в советско-японской войне и их последствия (1945-1956 гг.) / С. В. Карасев. - Иркутск: Изд-во ИрГТУ, 2006. - 354 с.

[7] Карасев С. В. История плена: советско-японская война и ее последствия (1945-1956 гг.): автореферат диссертации ... доктора исторических наук / С. В. Карасев. - Иркутск, 2007. $38 \mathrm{c.}$

[8] Карасев С. В. История плена: советско-японская война и ее последствия (1945-1956 годы): диссертация ... доктора исторических наук: 07.00.02. / С. В. Карасев. - Иркутск, 2007. 518 c.

[9] Серебренников С. В. Авторефераты диссертаций о японских военнопленных в СССР (19451956 гг.) как историографический источник / С. В. Серебренников // Историческая и социально-образовательная мысль. - 2016. - Том 8. - № 6. Часть 2. - С. 66-73.

[10]История пребывания японских военнопленных в советском плену в документах (19451956 годы): сб. документов / сост. С. В. Карасев. Изд-е 2-е, испр. Иркутск: НИ ИрГТУ, 2011. 112 с.

[11]Японские военнопленные в СССР: 1945-1956: сборник документов / сост. В. А. Гаврилов, Е. Л. Катасонова. М.: МФД, 2013. 784 с. 